\title{
The German limited and silent partnerships
}

\author{
by Frank Wooldridge
}

\section{INTRODUCTORY REMARKS}

Both the above types of entities exist in France as well as Germany. The limited partnership exists in the United Kingdom, but is not in frequent use; however it has been found valuable in the North Sea continental shelf oil industry. The German limited partnership is defined in paragraph 161 of the Commercial Code as a partnership carrying on a commercial activity under a common name in which at least one partner has unlimited liability towards the creditors, whilst at least one of the other partners is liable only for the amount of his capital investment. A silent partnership is defined in accordance with paragraphs 230(1) and 231(2) of the Commercial Code as a personalistic entity in which the silent partner participates in the commercial enterprise conducted by the active partner in such a way that an investment is made by it in the assets of the active partner, and the silent partner participates in the profits of that undertaking. No such corresponding entity is provided for under United Kingdom law.

In the text below the German limited partnership is considered before the silent partnership; both entities, especially the former, are of considerable economic importance in that country.

\section{THE LIMITED PARTNERSHIP}

\section{Nature and some important characteristics}

The limited partnership is simply a special form of the ordinary commercial partnership. In principle, the ordinary partners (Komplemtäre) are responsible for the running of the partnership, and have unlimited liability, whilst the limited partner(s) are excluded from the management and representation of the partnership. However, the special rules governing the limited partnership, which are principally contained in paragraphs 161-177a of the Commercial Code, are of a flexible nature and may depart from this model. In addition to these special rules, the limited partnership is also governed by the rules contained in paragraphs 105-60 of the Code, which are made applicable to the commercial partnership. The members of the partnership may be natural persons, or corporations having legal capacity or personalistic associations such as the GmbH (Gesellschaft mit beschränkter Haftung) or private limited liability company. A civil partnership may be the limited partner or Kommanditist. A limited partnership does not have a legal personality, but is instead treated as a community of joint owners. Many of the rules applicable to the limited partnership are the same as those governing the ordinary commercial partnership: see paragraphs 105-160 of the Commercial Code, to which paragraph 161 makes reference.

The articles of a limited partnership must state the nature of the contributions and stipulate that the liability of a limited partner is limited to a specific amount of money, or that he is required to provide certain things for the partnership, which have to be given a specific value therein. A limited partnership requires entry in the Commercial Register, which is maintained by the local commercial court. It has to be given a name, followed by a suffix which indicates its legal form.

According to paragraphs 123(1) and (3) and 161(2) of the Commercial Code, the limited partnership comes into existence once it has been entered in the Commercial Register. However, if an entity has been carrying on transactions before registration, and it has the characteristics of a commercial enterprise, such transactions are binding on the limited partnership and third parties in accordance with paragraph 123(2) of the Commercial Code. A different approach is taken when the relevant transactions are not of a commercial nature, when they are not so binding. By paragraph 176(1), if a limited partner agrees to the commencement of business before registration, he (or it) will incur unlimited liability in respect of the transactions concluded before such registration unless the relevant creditors are aware that he (or it) is only a limited partner. It is obviously generally in the interests of such a partner to endeavour to ensure that no pre-registration transactions take place.

The German limited partnership has grown in importance in recent years. Various forms of the $\mathrm{GmbH} \&$ $\mathrm{CoKG}$, in which the $\mathrm{GmbH}$ is frequently the unlimited partner and the directors thereof may be the limited partners, have long been in use in that country. Originally the use of this type of business entity was motivated by considerations of taxation. The limited partnership is also used for the purpose of family businesses. Certain KG, the so-called Publikums-KGs, have a considerable number of members whose membership has resulted from the 
advertisement of a particular project and who are treated as limited partners, as well as other unlimited partners. Such entities may enjoy certain tax advantages, but have sometimes been used for fraudulent purposes.

\section{The position and liabilities of the partners}

The rules governing the rights and duties of the unlimited partners are similar to those governing the partners in an ordinary commercial partnership (offene Handelsgesellschaft, $O H G$ ). Thus the unlimited partners are normally entrusted with the management and representation of the partnership in accordance with paragraphs 114 et seq and 125 et seq of the Commercial Code and are not permitted to compete with the partnership. In addition, unless the articles provide otherwise, they have a right to withdraw funds from the partnership (Entnahmerecht) similar to that enjoyed by the partners in an ordinary commercial partnership.

The limited partners are excluded from the management of the ordinary business of the company (Commercial Code, para 164) but their assent to extraordinary transactions is required. They are granted certain controlling rights by paragraph 166 , for example the right to examine the balance sheets and the partnership books. Sometimes a limited partnership which invites subscriptions from the public has a supervisory board made up of limited partners which exercises the rights to assent to extraordinary transactions and the controlling rights given by paragraphs 164 and 166 respectively. It is possible for the articles of the partnership to grant more extensive rights to the limited partners than those given by paragraph 164 of the Code; the limited partners may thus be given the right to issue instructions to the unlimited ones. The limited partners as well as the unlimited ones have the duty of acting in good faith towards the partnership: this duty of the limited partners does not seem so far-reaching as that of the unlimited ones. Unless the articles provide otherwise, the limited partners (unlike the unlimited ones) are not prohibited from competing with the partnership (note in this sense Kübler and Assmann, Gesellschaftsrecht, $16^{\text {th }}$ ed, F Müller Verlag 2005, p 105). Clauses restricting such competition must be compatible with German competition law and European Community law.

The assets of a limited partnership are in the collective ownership of all the partners, including the limited ones. The amount of a partner's share in the partnership's capital determines his participation in the partnership profits and liquidation surplus. The shares of the individual partners in a limited partnership may differ in amount. That of a limited partner is dependent on the amount of his contribution to the partnership's assets, and may not exceed that amount. Each partner is entitled to a 4 per cent dividend from the annual profits. The remainder of such profits, together with any losses have to be allocated appropriately (angemessen), in accordance with paragraph
168(2) of the Commercial Code. Any losses are written off the value of the partners' shares. If the value of a limited partner's share falls below his original contribution, or becomes negative, it has to be restored to its original amount before any dividends may be paid (Commercial Code, para 169(1)). A limited partner is only required to pay any outstanding amount of his contribution in the dissolution of the partnership.

According to paragraph 170, a limited partner has no right to represent the partnership. If he is permitted to represent it in respect of transactions with third parties, he loses his limited liability. However, it is possible to grant him a power of attorney (Handlungsbevollmacht) or a full power of representation (Prokura) in accordance with paragraphs 48 et seq of the Commercial Code. Certain transactions of a fundamental nature, including the sale of the business and all its assets require the consent of the limited partners (Kübler and Assman, op cit, p 106).

The creditors of the partnership may demand satisfaction from the unlimited partners out of their own assets, in accordance with paragraphs 124(1) and 161(2) of the Commercial Code. The liability of the limited partners to such creditors is governed by paragraph 171(1) of the Code, and only extends to the amount of the contribution. The limitation of liability is dependent on the partnerships being entered in the Commercial Register. Unlimited liability will be imposed on limited partners in respect of pre-registration of transactions if after such registration the relevant entity had engaged in commercial transactions and such limited partners had then agreed to the continuation of business.

The limited partner is no longer liable once the relevant contribution is made. This may take the form of the provision of cash, things, rights or services. Such contributions have effect as against creditors in accordance with their market value. Contributions may take other forms, for example the set-off of a debt due from the partnership or the failure to accept dividends due to the limited partner. It follows from paragraph 172(4) of the Commercial Code that the limited partner's liability in respect of his contribution revives if this, or part thereof, is returned to him, for example through the payment of dividends to him when the value of such contribution has been reduced as the result of losses incurred by the partnership. If the other partners agree to the release of such liability this has no effect against the partnership's creditors. Paragraph 172(5) of the Code provides that dividends which have been distributed in good faith on the basis of a proper balance sheet and payments thereof received in good faith do not have to be returned to the partnership by a limited partner.

If a person becomes a limited partner in an existing commercial partnership, he has limited liability for the latter entity's debts which have already been incurred, in accordance with paragraph 173(1) together with 
paragraphs 171 and 172 of the Commercial Code. It is irrelevant whether the existing firm is continued or a new one is set up. Such limited liability is, however, dependent upon the entry of the limited partner's name in the Commercial Register. The Commercial Code does not contain any special provisions governing the withdrawal of a limited partner from the partnership. It is clear however, that if he has not made his contribution in full he is liable for the residue to the existing creditors: the limitation period in respect of such liability is a short one of five years. If such a partner who has made his contribution in full receives compensation out of the assets of the partnership in respect of such withdrawal, he is liable to the creditors of the limited partnership in respect of such compensation (Commercial Code, para 172(4)).

\section{THE SILENT PARTNERSHIP}

\section{Nature, forms and significance}

The nature of this entity has been explained briefly in the introduction. It used to be regulated by paragraphs 335-342 of the Commercial Code, but since the enactment of the Bilanzrichtliniengesetz in 1985, it has been dealt with in paragraphs 230-37 of that Code, which are of a dispositive rather than a mandatory character and somewhat fragmentary. It is also subject to paragraphs 705 et seq of the Civil Code. German textwriters refer to it as an Innengesellschaft: this indicates that there are no legal provisions governing the external relations of such an entity because it does not engage in them. Such Innengesellschaften, of which the silent partnership is the prime example, are governed by the law of obligations (Schuldrecht), which regulates their internal affairs. As they have no external relations, such entitles are not entered in the Commercial Register.

As mentioned above, a silent partnership is treated as a personalistic entity (Personengesellschaft). Such entities also include limited partnerships, ordinary commercial partnerships and private limited liability companies. A person or entity which binds himself or itself by a suitable contract may become a silent partner, which may be a natural person or a juridical person or an entity under the regime of collective ownership, for example a commercial partnership or a limited partnership. The other party to a silent partnership must carry on an undertaking, and thus be a capitalistic entity, such as a public company or a cooperative, a personalistic entity, or a sole entrepreneur.

It is sometimes difficult to distinguish a silent partnership from a contractual arrangement involving the exchange of benefits (Austauschvertrag). However, if a natural person, a legal person or an entity which is collectively owned by its members participates in the profits or losses of the relevant undertaking, the arrangement will be treated as a silent partnership. A similar approach may be taken where the relevant person or entity is given extensive rights of supervision or control over, or the right to give assent to changes in the objects of, the undertaking. The relevant contract has to be considered as a whole in order to determine its nature.

A distinction is often made between typical and atypical silent partnership. A typical silent partnership is thought of as having only two members, the undertaking or active partner and the silent partner. Such an arrangement only gives the silent partner the right contained in paragraphs 230-37 of the Commercial Code. The contribution made by the silent partner to the relevant undertaking is not treated as equity capital (Eigenkapital) but as loan capital (Fremdkapital). A silent partnership may deviate in certain ways from the above model: thus the silent partner's holding may be treated as part of the assets of the active partner. Furthermore, the silent partner may have management functions in that undertaking. The silent partner may also have the status of a limited partner in the undertaking (see K Schmidt, Gesellschaftsrecht, $3^{\text {rd }}$ ed, pub C Heymanns Verlag, Munich 1997, in this sense).

The investment in a silent partnership may take the form of patents or copyright or of cash. Only the active partner take part in legal transactions. The silent partnership is used for the purpose of giving medium term loans to undertakings and as a useful facility for other purposes, for example that of making provision for family members, and for persons withdrawing from ordinary commercial and limited partnerships. In recent years, a considerable amount of use has been made of the $\mathrm{GmbH}$ \& Still. In such an entity, the silent partner and the $\mathrm{GmbH}$ (private limited liability company) combine together to form a single organisation. The silent partner may be a member of the $\mathrm{GmbH}$. This type of silent partnership is used for the purpose of accumulating capital. It has tax advantages in addition to the limited liability enjoyed by the private company.

\section{Rules governing the silent partnership}

Since the silent partnership has no external relations it is not represented either by the silent or the active partner (Komplementär). However, the silent partner may be granted a power of commercial representation (Prokura) to act on behalf of the active partner in the undertaking. The active partner, as opposed to the silent partner, is liable for the trade debts. A silent partnership in essence involves contractual relationships between the participants. It is required to make the promised contributions to the assets of the active partner. That partner is required to conduct the business in the general interest and to pay the silent partner an annual dividend (Commercial Code, para 232(1)), and when the partnership has terminated to pay the silent partner the appropriate credit balance (Commercial Code, para 235(1)). The silent partner must participate in the profits of the partnership, and in its losses, unless there is an agreement to the contrary.

The management of the partnership is entrusted to the active partner: according to paragraph 233 of the Code, 
the silent partner has only a limited right to receive information. However, in certain untypical silent partnerships the silent partner is given the right to object to or approve proposed actions of the management, and give instructions to the managers. Sometimes the silent partner is entrusted with management functions itself. An active partner in a silent partnership is only required to exercise the same degree of care as that which that partner would exercise in the conduct of its own affairs (see Civil Code, para 708). It is doubtful however whether this rule would apply where the silent partnership had the character of a large entity inviting subscriptions from the public, or Publikumsgesellschaft (see Kübler and Assman, op cit, p 114 in this sense).

A silent partnership has no assets of its own, and thus when it terminates there is no liquidation procedure. Once a ground for dissolution occurs according to the law, the silent partner is entitled to claim the credit balance due to him (or it), in accordance with the relevant balance sheet. The position of such a partner is different from that of a limited partner in this respect, because the silent partner is treated as a qualified creditor of the partnership. If insolvency proceedings are begun against the assets of a partner, the silent partnership is treated as dissolved. If the active partner becomes insolvent, paragraph 236(1) of the Commercial Code provides that the silent partner may prove for his credit balance (which is likely to have been diminished through losses) in its insolvency, and that partner will have the same rank as the other creditors who do not have preferential claims and will be entitled to the same insolvency quota as such creditors.

Dr Frank Wooldridge 